\title{
Tryptic Digestion
}

National Cancer Institute

\section{Source}

National Cancer Institute. Tryptic Digestion. NCI Thesaurus. Code C68835.

A technique for proteolysis of proteins into peptides at lysine or arginine by treatment with the pancreatic enzyme trypsin. 